\title{
The study of appropriate technology for green transformation for existing public buildings - A Case Study of Nanjing
}

\author{
Li Ming-hui ${ }^{1, a^{*}}$, Feng Xiao-tong ${ }^{2, b}$, Cong Yuan-wei, \\ 1 Jinling Institute of Technology, Nanjing, China \\ 2 Jinling Institute of Technology, Nanjing, China \\ ${ }^{3}$ Jinling Institute of Technology, Nanjing, China

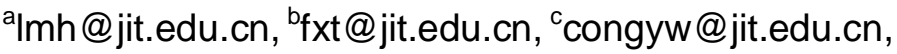

Keywords: green; transformation; technology

Abstract. Site investigation and monitoring on public buildings in Nanjing, analyses on the status and existing problems. Put forward the objective and principle of green transformation, raised the appropriate greening technology reform and seismic strengthening technology. The energy consumption of buildings' total life cycle is minimal.

\section{Green transformation's Present Situation and Existing Problems of existing public buildings in Nanjing}

According to research, Most of existing public buildings are not energy-efficient before 2005 in Nanjing. General consumption of public buildings are in $100-300 \mathrm{~kW} \cdot \mathrm{h} / \mathrm{m}^{2}$, which about $50 \%$ to $60 \%$ consume in air conditioning and refrigeration and heating systems, $20 \%$ to $30 \%$ for lighting. Energy consumption of public buildings is 3 to 5 times than residential buildings; wherein the consumption of office buildings is between 80 and $150 \mathrm{~kW} \cdot \mathrm{h} / \mathrm{m} 2$ by central air-conditioning. Since the seismic intensity of Nanjing is 7, some old public buildings which located in Old City and built in the 1970s have some seismic hazard. This part of the building in larger quantities, broader, once the earthquake happened, which will bring great losses.

\section{Green transformation's Objectives and Principles of existing public buildings in Nanjing}

\section{Transformation objectives}

Nanjing is the typical summer heat and winter cold city, which located in the middle latitudes, subtropical monsoon climate and significant effect of monsoon. Green transformation of existing public buildings mainly involves building envelope, heating systems, heating and cooling systems, lighting equipment and hot water supply systems. The goals of transformation are: (1) the integrative energy-saving retrofitting for envelope, mainly about roofs, exterior walls, doors and windows. (2) the integrative energy-saving retrofitting for thermal system, mainly about water systems running and electric operation system. (3) the integrative energy-saving retrofitting for building function improved, seismic reinforcement, renewable energy applications.

\section{Transformation principles}

(1) Balanced and focused. The key of retrofit scheme is to choose less input, leading role, good benefit's large public buildings, government and schools, hospitals and other public welfare projects. Combined with the old cities turn to new, regulation community environment, improvement of 
urban landscape, building renovation, seismic strengthening, Pushed by instalments and coordination.

(2) Suitmeasures to local conditions, reasonable use. Retrofit scheme is depended on the climate characteristics, current status and the use of public buildings in Nanjing. In view of the nonprofit of public buildings, combining with the social and economic development and the requirement of urban happiness, greening transformation to highlight the people-oriented, moderate in advance.

(3) Government and market become a driving force for advance. Green transformation of existing public buildings is wide, which should rely on the dominant role of the policy of government and market. Create a green transformation's demonstration area and project group, encourage enterprises to participate in actively, gradually explore from single building green to building demonstration area, from single technology to synthesis technology, which can link green transformation with industrial, cultivating green low carbon building industry development, and form local industry, which is featured by new energy, new materials and the equipment manufacturing industry.

\section{Green transformation's appropriate technology of existing public buildings in Nanjing}

According to the Greening reform goals and principle of existing public buildings, combined with the research, to determine the appropriate technologies. This paper mainly studies the integrative energy-saving retrofitting for envelope, like building function improved, seismic reinforcement, renewable energy applications.

Table1 Green transformation appropriate technology of existing public buildings in Nanjing

\begin{tabular}{lll}
\hline Public building types & $\begin{array}{l}\text { Main contents and orders of Green } \\
\text { transformation }\end{array}$ & Appropriate Technology \\
\hline $\begin{array}{l}\text { Gymnasium, } \\
\text { supermarket, } \\
\text { theartment, }\end{array}$ & $\begin{array}{l}\text { lighting equipment, } \\
\text { heating system, } \\
\text { heating and cooling systems, } \\
\text { enclosure structure }\end{array}$ & $\begin{array}{l}\text { Building lighting energy saving system: Attach } \\
\text { importance to the use of natural light, instead of } \\
\text { energy-saving lighting equipment. And using } \\
\text { intelligent control, strengthen the management of } \\
\text { energy efficiency }\end{array}$ \\
$\begin{array}{l}\text { enclosure structure, } \\
\text { heaching building, } \\
\text { office building, }\end{array}$ & $\begin{array}{l}\text { Enclosure structure reconstruction: Exterior Wall } \\
\text { heating and cooling systems, } \\
\text { lighting equipment }\end{array}$ & $\begin{array}{l}\text { External Insulation, combined External Sunshade } \\
\text { System with photovoltaic power system, outer } \\
\text { window glass system reconstruction, planting roof or }\end{array}$ \\
& $\begin{array}{l}\text { wall } \\
\text { heating system, } \\
\text { heating and cooling systems, } \\
\text { hot water supply systems, } \\
\text { enclosure structure }\end{array}$ & $\begin{array}{l}\text { See gas as primary energy sources for power and heat } \\
\text { or cold by power waste heat, meanwhile, output } \\
\text { electric energy, heat (cool) energy to users }\end{array}$ \\
\hline
\end{tabular}

\section{Integration energy saving reconstruction of Building Envelope (Roof, Door and Window, Exterior Wall)}

By researching, better reconstruction effect measures, in order: south to add visor, window with hollow and double-layer glass, exterior wall adding external insulation, roofing for planting roofing, etc. The following is introduced respectively.

Energy Saving Technology of Roofing

Roof are an important part of overall energy-saving in building, Roofing heat loss is $5 \% \sim 6 \%$ in total residential buildings, next to Exterior Wall, Door and Window and Staircase.

(1) Planting roof. Changing original roof into planting roof. Light materials, like perlite, vermiculite, to be as planting soil. Soil thickness must be conducted design calculation, planting 
layer container material can use lightweight bamboo, wood, engineering plastics, etc. Plants should be heat-resistant, wind-resistant, drought tolerance, tolerance to barren soil and shallow root system of plants. Nanjing area can use these planting soil, like stonecrop, stringy stonecrop, coleus, golden dewdrop, common dayflower. And according to the different load of roof and plant configuration requirements, formulate planting layer height. To improve waterproof property for roof, which can add a layer of 1.5-2.0 cm thickness's ash portland cement mortar in the original waterproof layer and ash Portland cement mortar and then turns the soil to grow later plant, cover the soil to plant.

(2) Inverted insulation roof. Adding insulating layer and invert it on the original roof. Inverted insulation roof is place insulating layer on the waterproof layer, which can prevent the insulating layer's inner for condensation and have good insulating ability.

(3) Shallow layer roof. Changing original roof into shallow layer roof. Turn roof into a shallow pool roof type collector, roof for load bearing and enclosure, at the top of the pool equip with a push and pull off the insulation plate. Roof as a collector and heat reservoir, make buildings in winter heating and summer cooling.

(4) Slope roof. Changing original roof into slope roof. The construction of Nanjing Old City proper mostly is flat roof, which can make into roofing, cornice and ridge ventilation or skylight ventilation, and equip with thermal insulation material, which not only can improve the thermal performance of roof, but also provide new space.

\section{Energy Saving Technology of Door and Window}

The area of the window in outside usually accounts for only about $25 \%$ of the retaining structure, but its energy consumption accounts for more than 50\%. The window energy saving mainly consider on the glass and profile. The kinds of glass are double deck glass, hollow glass, thermal reflective glass, coated glass, low-e glass (low e glass), etc. Profiles are mainly composed of aluminum alloy. According to the characteristics of the use of glass to choose matching window frame, at the same time, together with the shading system can achieve ideal energy saving effect.

(1)To modify the original outside window. To preserve metallic window frame for original unspoiled glazing, changing window leaves into insulating glass windows or meet the energy requirements of the glass and deal with original window, then install a layer of plastic window casing, thus, indoor decoration will not damage, but the energy saving effect is reduced. Besides, install an energy-saving window casing On the outside of the original window, form double window with original window, which have summer heat insulation and winter heat preservation and improve the function of window sound insulation effect.

(2)The window of energy-saving. Energy-saving effect of door and window is depend on heat transfer coefficient and airtightness of door and window, we can adopt the following. (1)Aluminum alloy doors and windows of energy-saving heat insulation break bridge have high strength, insulation, heat insulation, deadening, high resistance to wind load, airtightness, water tightness, long life could be used repeat. (2)Energy-saving frp doors and windows have the characteristics of lightweight and high strength, energy saving and thermoinsulating, corrosion resistance. (3)Energy-saving door and windows of Composition have good characteristics of appearance, insulation, wind-resistant, airtightness.

(3)Adopt the technology of external sunshade. It is the means of external window and transparent curtain wall. shading effect can be measured by the concept of shading coefficient, then ,compared with energy-saving standard. The shading coefficient of glass is determined by the 
solar radiation of glass and no overshadow transparent glazing with $3 \mathrm{~mm}$ thickness, smaller shading coefficient, less solar radiation .

When choosing external blinds, we should consider climate characteristics and the using demand of the room and the orientation of window. The shading effect of shutter or external shutter is better, it can adjust the Angle of the visor according to the changes of sun's position and gloom in the sky. Shading effect is depended on its forms, shading facilities' construction treatment, installation position, materials and so on.

Besides, shading system can combined with photovoltaic generation system, which achieved efficient sunshade and photoelectric conversion. The electricity can be used as the drive power of sunshade system and can be converted into power network system by conversion, to realize the efficient utilization of solar energy.

Energy Saving Technology of Exterior Wall

Energy saving technology of wall is divided into three types, include hydrophobic expansive pearlite external wall, external wall with insulation, exterior wall external insulation. When reform existing buildings, exterior insulation technology has significant advantages $\{5\}\{6\}$. Due to many old buildings in Nanjing have the characteristics of poor thermal performance, large energy dissipation, indoor wall dew, mildew and poor environment in winter. When adopt exterior wall external insulation to reform, it can protect main structure and reduce the change of temperature stress, and when construction, it doesn't affect the normal use of indoor, it is especially important for hotels, shopping malls.

(1) The technology of exterior wall external insulation. Mainly includes: Isolated Fire polystyrene board exterior insulation systems, exterior insulation decorative integration board, polyurethane exterior insulation system powder particles of polystyrene insulation slurry exterior insulation system. Common presentation were described as following.

(1) Polyurethane exterior wall external insulation system. It used coating or brick veneer, spraying polyurethane rigid foam in side, which have short drying time, good integrity, high strength, good flexibility, enhancing waterproof property.

(2)Colloid powder polyphenylene grain thermal insulation mortar exterior wall external insulation system. It consists of powder material and polystyrene particles aggregate, which have better thermal insulation performance, strong adhension, better anti-cracking performance, strong fire-resistant ability, strong wind resistance, which adapt to wall surface, door and window, corner, ring beam and column, it is easy to operate. Insulation layer using the plaster molding, and the base wall was dealed with interface mortar, the water absorption of different materials have consistent adhesion; Insulating layer is a whole and jointless; Crack Resistant Mortar has better crack resistance, water-resistance and osmosis.

(2) Greening and heat insulation on exterior wall. Summer is hot in Nanjing, For green transformation of northern exterior wall, the first choice is to see vertical greening as effective insulation method. this method not only does need small floor area, quick results and beautify the environment, but also can effectively reduce solar radiation and surface temperature of wall. 


\section{Energy-saving renovation with function improvement, seismic strengthening and adopting renewable energy sources}

The technology of seismic strengthening

Most existing public buildings need to do seismic strengthening in Nanjing, which can be taken into consideration when carry on green transformation. Main appropriate technology as follows:

(1) The reinforcement technique of pasting fiber sheet. It use carbon fiber cloth or carbon fiber board resin paste on the component surface. Carbon fiber sheet with lightweight and high strength, this means' advantages similar to pasting steel plate, in addition to, corrosion resisting, moisture-proof. Almost don't increase the weight, lower maintenance cost, but should be fire prevention. It is suitable for all kinds of mechanical properties of concrete structural components and general structure.

(2) The reinforcement technique of pasting steels. It pastes steels on the outside of the concrete member and it is suitable for general bending, tensile reinforcement components under static effect. This method is very fast and almost no wet operation on side, it doesn't affect the normal operation of buildings when construct, and it has no significant effect on the appearance of the original structure and original clearance after reinforcement.

(3) The reinforcement technique of prestress. Adopting additional prestressed steel bars, steel wire or steel poles to reinforce the structure, which can greatly improve the bearing capacity, stiffness and crack resistance, taking small space after reinforcement and have good effect. It is suitable for the reinforcement of long-span structures and concrete member under heavily stress and heavily strain.

The use of renewable resources

(1) The utilization technique of solar energy.

(1) Solar water heating technology. The application of solar collectors centralized or household solar hot water system is to provide hot water for the guesthouse, the hotel building。 The technique has many features, such as simple construction, modest cost, widely used and it is suitable for buildings' storey-adding, roof maintenance, flat to change slope and other renovation project.

(2) Solar wall heating and ventilation technology. Collecting "redundant" solar energy of south-facing rooms to heat air, Then, the heated air was conveyed to northern-facing rooms by pipeline system. When reform it, in the exterior wall between south-facing windows to install solar panels, wall openings, linked with the solar wall duct laying in the hallway, deliver hot air to northern-facing rooms that need to supply heating to enhance winter comfort of northern-facing rooms. Which have following features; simple construction, low cost and it is suitable for buildings' storey-adding, expansion, renovation and other renovation project.

(3) Optic-electro and optic-thermal system. Forming optic-electro and optic-thermal system by applying solar photovoltaic cells, battery, inverter, control and interconnection. It makes the building from consuming energy into supplying energy, the energy generated can be storage independently and be hooked up to the application. When the power generated is greater than the user requirements, the excess power can be transported to the grid. Solar photovoltaic cells and integrated retaining structures design. Photoelectric conversion's device layout has slope type, flat pattern, curtain wall, shading, etc. According to the needs, we can install it in the building roof and adjacent carport, clearing, exterior wall. The beautiful appearance of solar photovoltaic cells also have special adornment effect. Photovoltaic technology products also have solar lighting, outdoor information display, light, etc. 


\section{(1) Ground Source Heat Pump Technology}

Ground source heat pump is a new energy technology that use hallow geothermal to carry on heating and cooling. It taken advantage of underground soil's capable of thermal storage. The ground source transferred heat to the building from the underground soil in winter, while cold energy were transferred to the building from the underground in Summer. The whole system only consume electric, no pollution. Due to circulating water were used circularly and have no wastage in buried pipe system, so it doesn't cause stratum settlement. It use less area than tradition and can be placed in the basement.

This system technology has the following characteristics. (1) Environmental protection. This system has no combustion process, avoid discharging any smoke and harmful substances. Constant temperature and humidity indoor, it is very comfortable. (2) Safety economy. Energy efficiency of this system is 3-4 times than tradition. Although the initial investment is slightly higher than other central air-conditioning system, but the operating cost can save 1/2-1/3and eliminating the boiler room, cooling tower and auxiliary tanks, storage tank, etc., there is no security risk, while stabilizing unit operating conditions. (3) Water-saving and land-saving. The system with soil as the source, to absorb or release energy, namely do not consume water, also won't cause pollution. At the same time the unit arranged flexibly, saving rooms and space.

\section{Engineering Application}

A university building is frame structure, a rectangular shape, five layers, flat area of each layer is about 1200 square meters. The teaching building was built in the $1980 \mathrm{~s}$, many times to decorate, local modification, at present there are still many problems. (1) Wall mottle, roof waterproof and ageing, doors and windows damaged severely, Envelope insulation performance is poor, large south window area, Strong solar radiation, poor indoor thermal comfort; (2) Water, electricity pipeline facilities aging, elevator has already been abandoned, water and power consumption is very large; (3) Lighting mainly adopts artificial lighting, Most of Luminaires are fluorescent lamp. Have no cooling ventilation indoor.

The use of the teaching building is mainly for the daytime, demand of energy consumption is larger, and the position of construction, layout, orientation and the adjacent buildings form have been fixed, cannot change. Due to limited funds for technical innovation, we often take following measures:

(1)Integration reconstruction of Building Envelope. (1)Taking the roof greening, peat muck as casing soil, planting stonecrop; (2)Taking outside louvered external sun- shading technology; (3) Taking hollow double low radiation glass Windows; (4)External wall take polyurethane exterior wall external insulation system; (5Lecture theater and meeting room's wall surface and ceiling take insulation panels to ceiling; (6)The west's outside wall using vertical greening, planting climbing plant, like ivy, etc.

(2) The transformation of energy equipment and facility. (1) Taking solar photovoltaic system; installing solar photovoltaic panels on roof, it is used to supply electricity use of teaching building; (2) Lighting is replaced by the fourth generation LED energy-saving lighting LED; (3Installing electric and insulation curtains in room; (4) Sinks use hydraulic time-lapse self-closing faucets, install infrared water-saving device on toilet; (5) Ammeter is packed separately, building energy consumption monitoring system. 
(3) Anti-seismic Strengthening Project. It is for bearing load enhanced, partial structure basically used the preparation of high efficient concrete and pasting fiber sheets strengthening technology to reinforce the teaching building.

(4) Transforming the surroundings of buildings. (1)Setting up greenbelt and planting tree, shrub, turf around the teaching building. (2)Combined with campus drainage transformation, setting rainwater collecting tank, adopting rainwater recycling technology, reclaimed water is used for toilet flushing, car washing and green area irrigation,etc. (3)Adopting pervious ground and laying permeable bricks. (4)Designing reasonable parking space.

\section{Conclusion}

Green transformation of existent public buildings must be adjust measures to local conditions, combined with the green building standards, linked with regional environment and lifestyle. Studying and popularizing appropriate technologies of green transformation for existent public buildings, it has important significance for Building Nanjing into a modern, international, humanistic green are.

\section{References}

[1] Huang K. Distribution and Operating Characteristics of Public Buildings'Energy Consumption in Jiangsu Province. Building Energy Saving. 2(2013) 48-51.

[2] Li M.H. Yang D.F. The Properties of the Energy Efficiency Buildings Materials for the Walls and Roofs in Nanjing Area. Building Energy Saving. 6(2008) 31-34.

[3] Wei Y.L. Research and Application on Adapted Technique of Energy Efficiency Reconstruction for Exisiting Office Buildings in Jiangsu Province. Jiang Su Building. 3(2010) 95-96.

[4] Xu F., Zhou A.D., Liu L. Application Technology of thermal insulation of building enclosure structure. Beijing: China Building Industry Press (2011).

[5] Zheng L. High. Construction Method of external wall insulation. Beijing: China Building Industry Press (2007)

[6] Mei Q. L., Li J. Aseismic consolidation and repair of Building. Beijing: China Building Industry Press (2008) 